\title{
EXPLORING PRE-SERVICE CHEMISTRY TEACHERS' PROBLEM SOLVING SKILLS ON VOCATIONAL CONTEXT-BASED LEARNING
}

\author{
Antuni Wiyarsi ${ }^{1}$, Muhd Ibrahim Muhammad Damanhuri ${ }^{2}$, dan Nur Fitriyana ${ }^{1}$ \\ ${ }^{1}$ Chemistry Education Department, Universitas Negeri Yogyakarta, Indonesia \\ ${ }^{2}$ Chemistry Department, Universiti Pendidikan Sultan Idris, Malaysia \\ email: antuni_w@uny.ac.id
}

\begin{abstract}
Abstrak
This research aimed to explore the effect of Context-Based Learning (CBL) with petroleum and polymer topics on pre-service chemistry teachers' (PsCT) problem-solving skills. Within pre-experimental research design, the study focused on the exploration of PsCT problem-solving skills. Through convenient sampling techniques, the sample of this study consistedof a total of 34 PsCT (10 males and 24 females), who enrolled into a vocational chemistry course. To collect the data, Rubric for Problem-Solving Skills (RPSS) were used to measure four aspects of problem-solving skills (namely identifying problems, collecting information, providing possible solution(s), and communicating a possible solution). These data were analysed according to descriptive statistics and one-way ANOVA. Three openended questions were used to explore their views of relevance, usefulness, and effectiveness of the CBL. There was a significant difference between the PsCT' problems solving skills of petroleum and polymer topic. The results also indicated that their problem-solving skills had still fell into the sufficient category. Further, they found the implementation of the $\mathrm{CBL}$ is relevant, useful, and effective. Since the implementation of the CBL is promising to improve the PsCT's problem-solving skills, thus it should be encouraged to analyse any problem comprehensively and make an appropriate conclusion.
\end{abstract}

Keywords: context-based learning, pre-service chemistry teachers, problem-solving skills, vocational case

\section{INTRODUCTION}

The $21^{\text {st }}$ century learning system requires students to have and develop certain skills that involve critical thinking, problem-solving, creativity, innovation, and collaboration. Moreover, system thinking such as problem-solving skills has come to the attention of chemistry educators more predominantly in the past few years (Hrin, Milenkovic, Segedinac, \& Horvat, 2017). Problem-solving skills require to intellectually, logically, and systematically select the best solution of the problems (Ahghar, 2012) and bring them to achieve the goals in solving complex problems (e.g., Chaudhry \& Rasool, 2012; Yu, Fan, \& Lin, 2015). The problem-solving skills not only help the students in solving academic problems but also in all problems of the life fields (Armagan, Sagir, \& Çelik, 2009; Bolkan, Cakici, \& Cakici, 2012). A better students' problem solving skills, a high probability of success in any kind of activities in everyday life. Students with strong problem-solving skills are life-long learners which are able to analyse critically some daily complex problems. Students may find difficulties in solving the outside problems of the academic field since their lack of opportunities in problem-solving in a real-life context. It means that this skill will be useful for students toward their future life. Students that have become habituated to practice problem-solving can adopt a new environment for life easier. Therefore, enhancing problem-solving 
skills should be emphasized in chemistry learning both in high school and teacher education. They should develop students' thinking concerning real-life activities since it was promising to promote students' problem-solving skills (Gur \& Kocak, 2017).

Good problem-solving skills became an essential factor in determining students' success in learning chemistry (Suyanta, Laksono, Fadhilah, \& Rizky, 2019). Given the importance of students' problemsolving skills in supporting their learning outcomes, it is also needed to prepare the teachers with good problem-solving skills. Consequently, it should be prepared for the pre-service teacher during their teachers' preparation programme. Previous studies reported the effort in improving pre-service teachers problem-solving skills through several ways (e.g., Benli \& Sarikaya, 2012; Çalışkan, Selçuk, \& Erol, 2006; Mataka, Cobern, Grunert, Mutambuki, \& Akom, 2014; Ultay, 2017). They applied problembased learning to facilitate problem-solving skills and improve pre-service teachers' knowledge. Whereas other studies reported the use of context-based problem (e.g., environment, health) was improve students' thinking, motivation, and perception of science relevance (e.g., Ultay \& Calik, 2012; Demircioğlu, Ayas, Demircioğlu, \& Özmen, 2015; Ilhan, Yildirim, Yilmaz, 2016; Broman, Bernholt, \& Parchmann, 2018; Habig, et al., 2018; Eny \& Wiyarsi, 2019). This led to a new idea to use contextbased learning in facilitating problemsolving skills of pre-service chemistry teachers' (PsCT). Context-Based Learning (CBL) has come to be widely used in chemistry teaching to enhance the learning quality (e.g., Demircioğlu, Demircioğlu, \& Çalık, 2009; Acar \& Yaman, 2011; Vos, Taconis, Jochems, \& Pilot, 2011; Mataka \& Kowalske, 2015; Eny \& Wiyarsi, 2019).
Eventhough the choice of appropriate contexts is crucial for CBL approaches to actually increase students' achievements (e.g., Sevian, Hugi-Cleary, Ngai, Wanjiku, \& Baldoria, 2018; Broman et al., 2018), thus, choosing a context is relative to the circumstance of the study.

On the other hand, in the Indonesian national curriculum, chemistry is taught in general and vocational high schools. However, both programmes have a different purpose in chemistry subjects. Chemistry subjects in general high school aims to provide basic knowledge as a foundation to continue to higher education. While in vocational high schools, chemistry subject is expected to provide basic skills for students to develop their expertise competencies (Indonesian Ministry of Education, 2016). For instance, automotive engineering students learn hydrocarbons to understand more about vehicles fuel and combustion systems (e.g., Febrianto, Wiyarsi, Partana, \& Sulistyo, 2018; Wiyarsi, Pratomo, \& Priyambodo, 2020), the understanding of electrochemical concept as basic for comprehending combustion system and corrosion of vehicles components (Febiana, Partana, Wiyarsi, \& Sulistyo, 2018). That is, the teacher should use appropriate context in chemistry learning for vocational students. Furthermore, Faraday, Overton, and Cooper (2011) state that the context dimension of the vocational school covers the nature of vocational subjects, learning environment, the specification of students' qualifications, and students' learning styles. The discrepancy of learning purpose in general and vocational schools require the specific capabilities for PsCT such as gaining enrichment content related to students' competence. Hence, it is needed for restructuring of the curriculum for PsCT education programs that are more concerned with professional development 
in the context of vocational high schools (Wiyarsi, Hendayana, Firman, \& Anwar, 2017). It seems that the implementation of the CBL with vocational context as a problem is useful for PsCT to train their problem-solving skills. Also, this experience will support their achievement of chemistry overall.

Through the implementation of CBL with vocational cases, PsCT has a good experience to solve chemistry problems in several specific areas. PsCT will understand the steps and function of problem-solving skills and help them be an advanced chemistry teacher for a vocational school in the future. The study will lead off the extending of context-based chemistry learning focused on vocational school for chemistry teacher preparation. CBL will overcome the obstacle of PsCT to correlate the chemistry concepts with automotive engineering problems. Accordingly, the study also promotes the ability of PsCT in designing appropriate learning for vocational high school. Hence, it will be a model for PsCT to give meaningful chemistry learning for the vocational high school students. Finally, it will support the increase of chemistry learning quality. Thus, this research aimed to explore the effect of CBL with petroleum and polymer topic on PsCT' problem-solving skills especially with the context of automotivespecific expertise. The following research questions guide the study: how does the PsCT' problem-solving skills in the CBL implementation with the vocational case?, is there a significant difference in PsCT' problem-solving skills on petroleum and polymer concepts?, at which point do the skills of PsCT still lack and need to be improved?, and how does the PsCT' view about $\mathrm{CBL}$ implementation with a vocational case?

\section{METHODS}

Within pre-experimental research with one shot design, the study focused on the exploration of PsCT problem-solving skills on CBL implementation. Since it employed pre-experimental design, thus this research did not measure pre-test and set control group before the teaching intervention. This is seeming like a limitation of the current study, however the study intended to depict PsCT problem solving skills after perceiving CBL. Through a convenient sampling technique, the sample covered a total of 34 PsCT (10 males and 24 females) who enrolled in vocational chemistry course in this study. The research sample established from third year chemistry teachers' candidate enrolled in teachers' preparation programme from a public university in Indonesia. The ages of PsCT were 20-21 years old. The PsCT were randomly divided into 10 heterogeneous groups. Therefore, PsCT worked in small groups consisted of 3-4.

The topics used in CBL were related to chemistry concept that was taught in vocational high school and especially applicative in automotive field, namely petroleum and polymer topics. The CBL conducted in two stages and finished in six weeks. The first stage deals with petroleum topic for the first three weeks and the last three following weeks deal with polymer topics.

The CBL was implemented through discussion in small groups and individual work with several steps. A narrative text related to the issues of the petroleum and polymer topic were used to initiate the discussion. In the first meeting, the PsCT were work in their group aboutidentifying problems, collecting information, providing possible solution(s), and communicating a possible solution concerning the narrative text (see the example of the narrative text 
on Figure 1 that used in this research). The learning began when PsCT identified the problems according to the narration provided, compile the problems to be solved, and then construct the hypothesis towards the existing problems, thus there was no explanation by lecturer. Then, PsCT collect and record the information which needed in order to answer the problems. In this process, they were permitted to use any learning sources. The last step, PsCTs were elaborated their knowledge according to the information they obtained on the previous activity to answer the problems analytically and thoroughly. Then, in the next meeting, PsCT of some group presented the group discussion result in the class discussion. Another group shared their idea and questions. Lecturer gave feedbacks and strengthening about several concepts that were still consider to be confused by PsCT. In the last meeting, the PsCT work individually followed all steps such what they experienced in the first meeting. However, they work with different problem.

The data of PsCT' problem-solving skills were collected through observation using Rubric of Problem-Solving Skills (RPSS).

The aspects of RPSS were synthesized from several studies (e.g., Armagan, et al., 2009; Cheng, She, \& Huang, 2018;

Figure 1. The Sample of The Narrative Text on Petroleum Topic

Intense socialization was carried out by Pertamina (public oil company of Indonesia) on the use of non-subsidized premium and diesel fuel since 2013. The results give significant changing nowadays. The users of Pertamax and Pertamax plus in 2013 improve 20\% compared to 2012. Likewise, with the Pertamina DEX and Biosolar non-subsidized diesel consumption. According to Afandi, as the General Manager Marketing PT Pertamina Region III, this growth shows that the public is starting to realize the importance of using fuel which good and precise, in addition to reducing the APBN expenditures, it also means that the public is aware of the need to minimize the negative impact of using petroleum on the condition of engine and environment. On the other hand, the Riau Provincial Government assesses that the policy of limiting subsidized solar supplies has a good impact on the trade in Crude Palm Oil (CPO).

However, most people still complain the higher price of the high quality gasoline and diesel. Pertamax is not an ordinary product with a cheap price. There is additional technology to produce the Pertamax which bring the price is more expensive than the Premium or Pertalite as the ordinary product of gasoline. No wonder if in some places, there are creative people who are trying to make a gasoline that better than the Premium but with a cheaper price than the Pertamax by making a mixture of Pertamax and Premium.

On the other hand, the high demand of oil fuel in Indonesia recently inseparable from the rapid growing the number of vehicles, especially private vehicles. Increasing demand of motorcycle should be balanced with the additional services for motorcycle such as repair shop. From the repair shop activities also produced waste in the form of B3 waste including lubricants waste, batteries waste, and also a mechanic clothes that has been contaminated by solvents or lubricants. Although the lubricants waste still can be used, but if it is not managed properly, it will be harmful for the environment.

The increasing number of vehicles inevitably impacts the decline of the environment quality such as the air become dirty and hotter. Consequently, instead of the efforts to improve environmental quality, the government encourages the efforts to use fossil fuels effectively and efficiently and develop alternative energy sources that are considered feasible in terms of technical, economical and environmental aspects. 
Chua, Tan, \& Liu, 2016; Polya, 1945; Wehmeyer, Lattin, \& Agran, 2001).The RPSS which consisted of 13 items, covered four aspects i.e. identifying problems (4 items), collecting information (2 items), providing possible solution(s) (4 items), and communicating a possible solution (3 items). A group of experts (chemistry educators) looked over the RPSS to ensure the appropriateness of instrument. Based on the experts' suggestions, the RPSS was revised. For example, in the term of oral communication that belongs to the aspect of communicating a possible solution was deleted. Because according to the experts' suggestion, since the students were work in a small group therefore they presented the possible solution in a group, thus it will be difficult to observe their individual communication skills. Other revisions were made concerning the appropriateness of the criteria used in the RPSS, mistake in Indonesian grammar rule, and error typing. In addition, three open-ended questions were used to explore the PsCT's view about the relevance, usefulness, and effectiveness of the CBL implementation.

The data of PsCT's problem-solving skills on the petroleum and polymer topics were analysed according to the descriptive statistics. The possible response to the RPSS brought up the categories and frequencies. The mean scores were classified into five categories within the range of poor category if the mean score $<1.8$; 1.81-2.60 identified as a less good category; 2.61-3.40 signified sufficient category; 3.41-4.20 implied good category; and if the mean score $>4.20$ indicated a very good category. Moreover, one-way Analysis of Variance (one-way ANOVA) was used to examine the difference among the PsCT's problem-solving skills on the petroleum and polymer topics. As for the PsCT responses to open-ended questions were analysed qualitatively by grouping the similar responses.

\section{RESULTS AND DISCUSSION}

According to Table 1, the results indicated that overall PsCT problemsolving skills had still fell into the sufficient category. PsCT signified a less good category in providing possible solution(s) on petroleum topics and collecting information on polymer topics. Both on petroleum and polymer topics, the PsCTs' identifying problems skills equally good. Furthermore, in order to determine of PsCTs' problem solving skills among petroleum and polymer topics, one-way ANOVA was performed and the results presented in Table 2. As seen from Table 2, the ANOVA calculated that value of $F$ $(33)=7.746$ at $p=0.007$. It means that there is a significant difference in PsCT's problem-solving skills for petroleum and polymer topics. It can be inferred that

Table 1

The Category of Problem-solving Skills of PsCT on Petroleum and Polymer Topics

\begin{tabular}{lcccc}
\hline \multicolumn{1}{c}{ Aspect } & Petroleum & Category & Polymer & Category \\
\hline Identifying problems & 3.34 & Good & 3.58 & Good \\
Collecting information & 3.04 & Sufficient & 2.54 & Less good \\
Providing possible solution(s) & 2.30 & Less good & 2.95 & Sufficient \\
Communicating a possible solution & 2.62 & Sufficient & 3.49 & Good \\
Overall & 2.82 & Sufficient & 3.14 & Sufficient \\
\hline
\end{tabular}


Table 2

One-way ANOVA Result of PsCT'Problem-solving Skills in Petroleum and Polymer Topic

\begin{tabular}{llcccc}
\hline \multicolumn{1}{c}{ Aspect } & & $\begin{array}{c}\text { Sum of } \\
\text { Squares }\end{array}$ & $\begin{array}{c}\text { Mean } \\
\text { Square }\end{array}$ & F & Sig.* \\
\hline Identifying & Between Groups & 0.773 & 0.773 & 2.833 & 0.097 \\
problems & Within Groups & 18.009 & 0.273 & & \\
& Total & 18.782 & & & \\
Collecting & Between Groups & 4.250 & 4.250 & 8.162 & 0.006 \\
information & Within Groups & 34.368 & 0.521 & & \\
& Total & 38.618 & & & \\
Providing possible & Between Groups & 7.118 & 7.118 & 19.725 & 0.000 \\
solution(s), & Within Groups & 23.816 & 0.361 & & \\
& Total & 30.934 & & & \\
Communicating a & Between Groups & 12.654 & 12.654 & 29.591 & 0.000 \\
possible solution & Within Groups & 28.222 & 0.428 & & \\
& Total & 40.876 & & & \\
\hline
\end{tabular}

Ket: *statistical significance difference of 0.05

there is significant difference of PsCT' collecting information, providing possible solution(s), and communicating a possible solution skill.

Phrase differently, there was no different on the identifying problems skills.Based on PsCT responses to the open-ended question, it concluded that the PsCT has a positive view toward CBL implementation on its relevance, usefulness, and effectiveness. This relevance is related to the topic that is in accordance with the needs of $\mathrm{PsCT}$ to become a professional teacher in vocational high schools. The PsCT agrees that the topic had they learned is needed to support the development of professional and pedagogical competencies, the mastery of vocational content in Automotive Engineering, and more in-depth insight into the curriculum of vocational high schools.

Related to the usefulness of CBL implementation, The PsCT state that it helps them in developing thinking skills and increasing their self-efficacy to teach in vocational high school. The PsCT have positive opinions of the CBL effectiveness. The course is seeming as good, directed, structured, useful and support the readiness of PsCT to teach in vocational schools. Whereas opinions related to the reason that make the PsCT fewer conveniences are the number of tasks being a burden on their own, group members who are always the same make the PsCT bored, and the ineffective time during group presentation.

Enhancing problem-solving skills should be emphasized in chemistry learning both in high school and teacher preparation programme. Because the two educational programmes offer to develop their thinking concerning real-life activities and it was promising to promote students' problem-solving skills in chemistry. Thus, the implementation of CBL is strongly suggested in the chemistry teaching in order to provide meaningful chemistry 
learning and relevance with everyday life. The discussion concerning the results of the current study presented regarding the research questions aforementioned.

The PsCTs have a sufficient level of overall problem-solving skills for both, petroleum and polymer topics (see Table 1). CBL as the active learning approach provides the activities and reallife problems found by PsCT that beneficial in order to develop their thinking skills, understand the context, and connect the context with scientific discourse (e.g., King \& Henderson, 2018; Surif, Ibrahim, \& Dalim, 2013; Sevian et al., 2018; Ultay $\&$ Calik, 2012). The implementation of CBL has opened the PsCT's insight on the important concepts needed to overcome automotive-related problems. The PsCT could correlate the chemistry concept with automotive field in every chemistry learning. Moreover, CBL with open-ended problems is considered to give chance to PsCT in developing their problem-solving skills. Otherwise, the skills of PsCT that not optimal yet, may cause by the characteristic of the content knowledge. Within the scope of chemistry, petroleum and polymer content are included in the knowledge that is complex and involves many prerequisites knowledge. Moreover, in this case, chemistry concept uses for solving the problem in automotive context. Thus the prepared chemistry problems on the narrative text provides in the Figure 1. The PsCT with a lack understanding of concepts' application tends to have difficulties in using petroleum and polymer concepts to solve the real-life problems (Wiyarsi et al., 2020).

There was found significantly difference among PsCT' problem-solving skills on petroleum and polymer topic with the favour on polymer topic (see Table 2). The fact that the PsCT' problem-solving skills on polymer better than petroleum topic may result from their experiences. These experiences related to much more interaction with the concept and much more engage in a workgroup when solving the problems. Based on Indonesian National Curriculum, PsCT learn a limited concept without any concept application about petroleum and polymer during high school and first year of university level. Indeed, some of PsCT can take the elective course that concerned with Industrial Chemistry and Polymer Chemistry (Wiyarsi et al., 2017). However, the courses did not discuss the concept application on the automotive field specifically. Another experience revealed that working in a group affects PsCTs' problem-solving skills. Problemsolving scientific results of the same content were better in collaborative work than if it is done individually. Similarly, Winarti, Rahmini, and Almubarak (2019) reported that collaborative problem solving is promising as an alternative strategy in eliciting students' thinking skills. Therefore, through the group collaboration, PsCT can exchange ideas, listen to each other, accept each other's' ideas, and make decisions together. It gives a wider opportunity for them to promote reasoning and commonly improve their problem-solving skills.

In addition, the broader of context would allow the students to make a better connection among the chemistry concept to their daily life that brings an opportunity to investigate their own hypothesis perceived by themselves (George-Williams, Ziebell, Thompson, \& Overton, 2020). As suggested by Avikasari, Rukayah, and Indriayu (2018) that making chemistry learning relevant with daily life issues is beneficial to enhance students' interest in exploring a new chemistry knowledge. The learning experience related with exploring knowledge, referring the 
literature, the way in conducting inferences, interpreting and communicating are used as a way to develop the professional teacher (Garet, Porter, Desimone, Birman, \& Yoon, 2001). Furthermore, CBL becomes an alternative learning approach in order to achieve teacher education goals due to the emphasizing of the authentic and meaningful situations involvement (e.g., Wiyarsi, Sutrisno, \& Rohaeti, 2019; Eshetu \& Assefa, 2019). It serves as a foundation of PsCT' investigation skills development.

Observing the category and difference of the aspect of PsCT' problem-solving skills among petroleum and polymer topics on Table 1 and Table 2 respectively, there were signified that the PsCT problemsolving skills is not at the best level yet. It may generate from three aspects of skills that should be improved including collecting information, providing possible solution(s), and communicating a possible solution. Another aspect problem-solving skills namely identifying problems is gained a better category by PsCT. The findings on this research confirmed previous study by Ozgen (2019) that a good students' problemposing skills leads to the students' easiness in identifying a problem. In this study, every PsCT needs to write important information based on narrative text that used as a basis in formulating the problems that should be solved. Through this activity, the PsCT practice their critical thinking in selecting the important information and deciding the problems that appeared according to the chemistry point of view and directly correlate into the automotive field.

The first aspect of PsCT' problemsolving skills that need to be improved is the collecting information from a reliable source skill. The expected skills concerning this aspect covering the collecting information from a references in the form of scientific journals, textbook for university students, and published and unpublished scientific articles. However, in this research, most of the PsCT' only access the information from the internet in the form of private weblog and high school chemistry books. The information provided by private weblog is not recommended due to the information were not reliable and accountable. While, the information on high school chemistry books is limited. The findings of this research also revealed that most of PsCT had the most difficulties in finding the learning sources about polymer on the automotive fields. The fact that most of PsCT have not been accustomed to find an international literature sources, both textbooks and journals brings up the results of recent study. It has been proven because there were already many journals and textbooks discussing about polymer and has been developed for the automotive field. For example, the thermoplastic olefin elastomers which used as exterior accessories, sound absorbers, instrument panels and polypropylene for replacement plate materials in the car's interior and car hood. The skills in collecting information from reliable sources need to be improve by giving a knowledge on how to access the primary learning sources about the discussed topics.

The second aspect of problem-solving skills that had a poor category and need to be enhanced was providing possible solution(s). The PsCT should provide as much as possible solution(s) of the problems and explain the rational and scientific reasons of the problems. The PsCT ability in processing the information and using the chemical understanding to answer the problems will be seen in this process. It can't be denied that the PsCT' prior knowledge and experiences in the term of chemistry content gives a significant effect towards their ability in solving the problems. The result of this study confirmed 
by Esen-Aygun (2018) that pre-service teachers who are cognitively flexible are able to solve problems constructively and persistently. As a consideration, CBL needs extra-situational knowledge from the context not only from science declarative knowledge but also its application in the everyday life (Herranen, Kousa, Fooladi, \& Aksela, 2019). Thus, PsCTs require this kind of extra-situational knowledge in order to provide possible solution(s).

On the other hand, the difficulties may arise from the emergence of sharp differences between group members that affect group effectiveness in elaborating all knowledge to determine a conclusion. The $\mathrm{PsCT}$ requires to claim a possible solution generated from data-based reasoning (Kim \& Pegg, 2019). The PsCT should describes the solution of the problems comprehensively with a deep analysis (Esen-Aygun, 2018). Thus, PsCT were required to provide scientific reasons from the solution given as clearly as possible through the elaboration of various knowledge. For example, when they asked about the difference between premium and pertamax. The solution of this problem not only refers to the price of the pertamax that more expensive or due to the higher of octane numbers of pertamax than premium. The two kindsof solutions should benot arising from PsCT. Because they have known the chemistry knowledge related the aforementioned topics, accordingly they should be giving another possible solution that more scientific based on chemistry concept of view. Thus, the appropriate solution concerning the problem should be by describing the difference quality from both gasoline according to the value of octane numbers. Hence, not only write that the octane number is higher but also describe how the octane numbers gives an effect on the quality of both gasolines.
The other example found when the PsCT were asked about the important reason of vulcanisation in the vehicle tire processing. The solution that should provide by PsCT not only limited on the improving of rubber elasticity, but also the emphasized on the reason of vulcanisation, itmakes the quality of rubber elasticity improved. The skills to give a comprehensive and thorough descriptions are needed to provide a better possible solution. In this case, it is not only critical thinking skills that needed, but also the ability to explain and provide scientific reasons in order to choose the best problem-solving solutions. This ability is related to the use of scientific argumentation. The $\mathrm{PsCT}$ should be able to express their ideas to solve the problem with proper scientific evidence. Enhancement of PsCT argumentation ability is requires to achieve deeper view in solving every automotive problem related to the application of petroleum and polymer concept. As suggested by Bağ and Çalık (2017) that scientific argumentation is influenced by initial knowledge, motivation, and classroom atmosphere. Therefore, the classroom atmosphere in active learning such as CBL could facilitates PsCT' in providing a good possible solution(s). Moreover, Sulaiman (2010) work revealed that the process in solving a problem needs the PsCT' ability to correlate the idea from their existing knowledge to provide an accurate solution of the problems. It means that the PsCT' skills in giving a comprehensive solution analysis can't be separated by their prior knowledge. The result of this study confirmed the previous study conducted by Chang (2010) and Overton (2013) that reported the ability in solving problems is affected by the cognitive level and science process skills of pre-service teachers. Furthermore, a good collaborative work is 
needed to achieve a better possible solution (Kelly, McLoughlin, \& Finlayson, 2016). Therefore, the implementation of CBL using small group collaboration is potential to develop providing possible solution(s) of problem-solving skills.

The last aspect of problem-solving skills that needs to be increased was communicating a possible solution because in this study, it signified a poor category. Concerning this aspect, previously many students were failed in drawing a conclusion due to the limited time allocation, they spent most of their time in making observations and collecting data (Kim \& Pegg, 2019). However, the expected ability from this aspect is drawing a conclusion from the possible solution(s) and presents it in the narration form. There were two deficiencies as the dominant factors found in groups collaborating PsCT' work, namely: writing the conclusion in the form of points but not represent from all of the given problems and drawing the conclusion in the form of very simple narration. The ability to draw a conclusion is not easy due to the PsCT require to be able to take and reveal the core of the problems. The result of Zhang Lundeberg, and Ebehardt (2011) works was support the result of this research that the ability to re-express is one aspect that plays important role in the successful of problem-solving process. The application of CBL facilitates students to construct their understanding through group collaboration. Hence, the implementation of CBL for vocational context should be further use.

The experience to solve problem in specific context is beneficial for the PsCT. Thus, they will apply their experiences to solve automotive problems that will increase the enthusiasm of vocational high school students. It will ultimately have an impact on improving the quality of chemistry learning. A positive view means that the PsCT have open-minded through the new experience. It helps the PsCT to enjoy the activities in solving the problem process. A good perception and feeling increase the PsCT problem-solving skills. Furthermore, CBL becomes an alternative learning approach in order to achieve teacher education goals due to the emphasis of the authentic and meaningful situations involvement (e.g., Wiyarsi et al., 2019; Eshetu \& Assefa, 2019). Through CBL, PsCT has the opportunities to construct their knowledge and develop the skills in applying chemistry concepts to the new situations including the vocational context through the effective interaction and collaboration.

\section{CONCLUSION AND IMPLICATIONS}

Concerning CBL implementation, it is one of the learning strategy based on the activities and real problems which play as an important role in providing opportunities for PsCT to enhance their problem-solving skills. Thus, the PsCT could develop the implementation of CBL into chemistry concept in a new environment such as the vocational context, effective interaction, and inquiry collaboration. The result of this research implied that the PsCT' problemsolving skills had a sufficient category, consequently it need to be enhanced especially in collecting information, providing possible solution(s), and communicating a possible solution skill. Hence, constructing scientific reasoning habits in problem-solving skills is needed to improve the three aspects of problem solving skills (Becerra-Labra, Gras-Marti, \& Torregrosa, 2012; Wiyarsi \& Çalik, 2019; Çalik \& Karataş, 2019).

This research suggests that constructing PsCT' problem-solving skills is required in order to fulfil a successful $21^{\text {st }}$ century learning system, still the thinking training could develop problem- 
solving skills (Gur \& Kocak, 2017). Moreover, the process in preparing preservice teachers should involve them in more number of cases in order to generate and enhance their problem-solving skills as suggested by Bars and Oral (2017). A better PsCT' problem-solving skills lead a meaningful chemistry learning in vocational high school that bring a better students' motivation and chemical literacy (e.g. Wiyarsi et al., 2020). Varying research sample in relation with the grades, perceiving into another chemistry topic, and utilizing blended learning as the learning equipment in the chemistry teaching (Fitriyana, Wiyarsi, Ikhsan, \& Sugiyarto, 2020; Wiyarsi et al., 2019) should be considered in the future studies in order to determine the effectiveness of CBL. Hence, the implementation of CBL should be valuable for chemistry learning at vocational high school.

\section{REFERENCES}

Acar, B., \& Yaman, M. (2011). The effects of context-based learning on students' levels of knowledge and interest. Hacettepe University Journal of Education, 40, 1-10.

Ahghar, G. (2012). Effect of problemsolving skills education on autoregulation learning of high school students in Tehran. Procedia Social and Behavioral Sciences, 69, 688694. https://doi.org/10.1016/j. sbspro.2012.11.462

Armagan, F. O., Sagir, S. U., \& Çelik, A. Y. (2009). The effects of students' problem-solving skills on their understanding of chemical rate and their achievement on this issue. Procedia Social and Behavioral Sciences, 1, 2678-2684. https://doi. org/10.1016/j.sbspro.2009.01.473.
Avikasari, Rukayah, \& Indriayu, M. (2018). The effectiveness of science literacy to improve science achievement. Jurnal Kependidikan, 2(2), 221-234. Retrieved from https://journal.uny. ac.id/index.php/jk/article/view/19167/ pdf.

Bağ, H., \& Çalık, M. (2017). A thematic review of argumentation studies at the K-8 level. Education and Science, 42, 281-303. https://doi.org/10.15390/ EB.2017.6845.

Bars, M., \& Oral, B. (2017). The relationship among metacognitive awareness, self-efficacy toward the teaching profession and the problem-solving skills of teacher candidates. Eurasian Journal of Educational Research, 72, 107-128. https://doi.org/10.14689/ ejer.2017.72.6.

Benli, E., \& Sarikaya, M. (2012). The investigation of the effect of problem based learning to the academic achievement and the permanence of knowledge of prospective science teacher: the problem of the boiler stone. Procedia-Social and Behavioral Sciences, 46, 4317-4322. https://doi. org/10.1016/j.sbspro.2012.06.247.

Becerra-Labra, C., Gras-Marti, A., \& Torregrosa, J. M. (2012). Effects of a problem-based structure of physics contents on conceptual learning and the ability to solve problems. International Journal of Science Education, 34(8), 1235-1253. http://dx.doi.org/10.1080/ 09500693.2011.619210.

Bolkan, A., Cakici, E., \& Cakici, M. (2012). Problem-solving skills and self-image of students' subject to disciplinary measurements. Eurasian Journal of Educational Research, 49, 1-12.

Broman, K., Bernholt, S., \& Parchmann, I. (2018). Using model-based scaffolds to support students solving context-based 
chemistry problems. International Journal of Science Education, 40(10), 1176-1197. https://doi.org/10.1080/09 500693.2018.1470350.

Çalik, M., \& Karataş F. Ö., (2019), Does a "Science, Technology and Social Change" course improve scientific habits of mind and attitudes towards socioscientific issues? Australian Journal of Teacher Education, 44(6), 34-52. https://doi.org/10.14221/ ajte.2018v44n6.3.

Çalışkan, S., Selçuk, G. S., \& Erol, M. (2010). Effects of the problem-solving strategies instruction on the students' physics problem-solving performances and strategy usage. Procedia - Social and Behavioral Sciences, 2(2), 22392243. https://doi.org/10.1016/j. sbspro.2010.03.315.

Chang, C. (2010). Does problem-solving = prior knowledge + reasoning skills in earth science? An exploratory study. Res. Sci. Educ, 40, 103-116. https:// doi.org/10.1007/s 11165-008-9102-0.

Chaudhry, N. G., \& Rasool, G. (2012). A case study on improving problemsolving skills of undergraduate computer science students. World Applied Sciences Journal, 20(1), 34-39. https://doi.org/10.5829/idosi. wasj.2012.20.01.1778.

Cheng, S-C., She, H-C., Huang, L. Y. (2018). The impact of problemsolving instruction on middle school students' physical science learning: Interplays of knowledge, reasoning, and problem-solving. Eurasia Journal of Mathematics and Technology Education, 14(3), 731-743. https://doi. org/10.12973/ejmste/80902.

Chua, B. L., Tan, O. S., \& Liu, W. C. (2016). Journey into the problemsolving process: cognitive functions in a PBL environment. Innovations in
Education and Teaching International, 53(2), 191-202. https://doi.org/10.108 0/14703297.2014.961502.

Demircioğlu, H., Ayas, A., Demircioğlu, G., \& Özmen, H. (2015). Effects of storylines embedded within the context-based approach on pre-service primary school teachers' conceptions of matter and its states. Asia-Pacific Forum on Science Learning and Teaching, 16(2), 1-30.

Demircioğlu, H., Demircioğlu, G., \& Çalık, M. (2009). Investigating effectiveness of storylines embedded within context based approach: A case for the periodic table. Chem. Educ. Res. Pract., 10(3), 241-249. https://doi.org/10.1039/ B914505M.

Eny, H. A., \& Wiyarsi, A. (2019). Students' chemical literacy on context-based learning: A case of equilibrium topic. Journal of Physics: Conference Series, 1397, 012035. https://doi.org/10.1088/17426596/1397/1/012035.

Esen-Aygun, H. (2018). The relationship between pre-service teachers' cognitive flexibility and interpersonal problem-solving skills. Eurasian Journal of Educational Research, 77, 105-128. https://doi.org/10.14689/ ejer.2018.77.6.

Eshetu, F., \& Aseffa, S. (2019). Effects of context-based instructional approaches on students' problem-solving skills in rotational motion. EURASIA Journal of Mathematics, Science and Technology Education, 15(2), 1665. https://doi. org/10.29333/ejmste/102283.

Faraday, S., Overton, C., \& Cooper, S., (2011). Effective teaching and learning in vocational education. London, UK: LSN.

Febiana, H., Partana, C. F., Wiyarsi, A., \& Sulistyo, B. (2018). Automotive 
engineering chemistry module: Exploring acid base and electrochemistry topic in vehicle context. Journal of Physics: Conference Series, 1156, 012023. https://doi.org/10.1088/17426596/1156/1/012023.

Febrianto., Wiyarsi, A., Partana, C. F., \& Sulistyo, B. (2018). Chemistry in context: The development of hydrocarbon chemistry and petroleum module based on vehicle case. Journal of Physics: Conference Series, 1156, 012021. https://doi.org/10.1088/17426596/1156/1/012021.

Fitriyana, N., Wiyarsi, A., Ikhsan, J., \& Sugiyarto, K. H. (2020). Androidbased-game and blended learning in chemistry: Effect on students' selfefficacy and achievement. Cakrawala Pendidikan, 39(3), 507-521. https:// doi.org/10.21831/cp.v39i.28335.

Garet, M. S., Porter, A. C., Desimone, L., Birman, B. F., \& Yoon, K. S. (2001). What makes professional development effective? result from a national sample of teachers. American Educational Research Journal, 38, 915-945. https:// doi.org/10.3102/00028312038004915.

George-Williams, S. R., Ziebell, A. L., Thompson, C. D., \& Overton, T. L. (2020). Inquiry-, problem-, contextand industry- based laboratories: An investigation into the impact of largescale, longitudinal redevelopment on student perceptions of teaching laboratories. International Journal of Science Education, 42(1), 1-18. https://doi.org/10.1080/09500693.20 20.1714788 .

Gur, C., \& Kocak, N. (2017). The effect of TMPT program on pre-school children's social problem-solving skills. Eurasian Journal of Educational Research, 73, 77-94. https://doi. org/10.14689/ejer.2018.73.5.
Habig, S., Blankenburg, J., van Vorst, H., Fecher, S., Parchmann, I., \& Sumfleth, E. (2018). Context characteristics and their effects on students' situational interest in chemistry. International Journal of Science Education, 40(10), 1154-1175. https://doi.org/10.1080/09 500693.2018 .1470349$.

Herranen, J., Kousa, P., Fooladi, E., \& Aksela, M. (2019). Inquiry as a context-based practice - a case study of pre-service teachers' beliefs and implementation of inquiry in contextbased science teaching. International Journal of Science Education, 41(14), 1977-1998. https://doi.org/10.1080/09 500693.2019.1655679.

Hrin, T. N., Milenkovic, D. D., Segedinac, M. D., \& Horvat, S. (2017). System thinking in chemistry classrooms: The influence of systematic synthesis questions on its development and assessment. Thinking skills and Creative, 23, 175-187.

Ilhan, N., Yildirim, A., \& Yilmaz, S. D. (2016). The effect of context-based chemical equilibrium on grade 11 students' learning, motivation, and constructivistic learning environment. International Journal of Environmental \& Science Education, 11(9), 31173137. https://doi.org/10.12973/ ijese.2016.919a.

Kelly, R., McLoughlin, E., \& Finlayson, O. E. (2016). Analysing student written solutions to investigate if problem-solving processes are evident throughout. International Journal of Science Education, 38(11), 1766-1784. http://dx.doi.org/10.1080/09500693.2 016.1214766 .

Kim, M., \& Pegg, J. (2019). Case analysis of children's reasoning in problemsolving process. International Journal of Science Education, 41(6), 739-758. 
https://doi.org/10.1080/09500693.201 9.1579391.

King, D., \& Henderson, S. (2018). Contextbased learning in the middle years: Achieving resonance between the realworld field and environmental science concepts. International Journal of Science Education, 40(10), 12211238. https://doi.org/10.1080/095006 93.2018.1470352.

Mataka, L. M., Cobern, W. W., Grunert, M., Mutambuki J., \& Akom, G. (2014). The effect of using an explicit general problem-solving teaching approach on elementary pre-service teachers' ability to solve heat transfer problems. International Journal of Education in Mathematics, Science and Technology, 2(3), 164-174.

Mataka, L. M., \& Kowalske, M. G. (2015). The influence of PBL on students' self-efficacy beliefs in chemistry. Chemistry Education Research and Practice, 16(4), 929-938. https://doi. org/10.1039/c5rp00099h.

Ministry of Education. (2016). Ministerial Regulation Number 22 Concerning Standard Content. Ministry of Education, Jakarta, Indonesia.

Overton, T., Potter, N., \& Leng, C. (2013). A study of approaches to solving open-ended problems in chemistry. Chemistry Education Research and Practice, 14, 468-475. https://doi. org/10.1039/C3RP00028A.

Ozgen, K. (2019). Problem-posing skills for mathematical literacy: The sample of teachers and pre-service teachers. Eurasian Journal of Educational Research, 84, 177-212. https://doi. org/10.14689/ejer.2019.84.9.

Polya, G. (1945). How to solve it. Princeton: Princeton University Press.

Sevian, H., Hugi-Cleary, D., Ngai, C., Wanjiku, F., \& Baldoria, J. M. (2018).
Comparison of learning in two contextbased university chemistry classes. International Journal of Science Education, 40(10), 1239-1262. https:// doi.org/10.1080/09500693.2018.147 0353.

Sulaiman, F. (2010). Students' perceptions of implementing problem-based learning in a physics course. Procedia Social and Behavioral Sciences, 7, 355-362. https://doi.org/10.1016/j. sbspro.2010.10.048.

Surif, J., Ibrahim, N. H., \& Dalim, S. F. (2013). Problem-solving: Algorithms and conceptual and open-ended problems in chemistry. Procedia Social and Behavioral Sciences, 116, 4955-4963. https://doi.org/10.1016/j. sbspro.2014.01.1055.

Suyanta, Laksono, E. W., Fadhilah, N. F., \& Rizky, I. (2019). The effect of problem-based learning on students' self-regulated learning of chemistry learnıng. Jurnal Kependidikan, 3(2). 187-193. Retrieved from https:// journal.uny.ac.id/index.php/jk/article/ view/19695/pdf.

Ültay, E. (2017). Examination of contextbased problem-solving abilities of pre-service physics teachers. Journal of Baltic Science Education, 16(1), 113-122. Retrieved from http://www. scientiasocialis.lt/jbse/files/pdf/ vol16/113-122.Ultay_JBSE_Vol.16_ No.1.pdf.

Ültay, N., \& Çalık, M. (2012). A thematic review of studies into the effectiveness of context-based chemistry curricula. Journal of Science Education and Technology, 21(6), 686-701. http:// dx.doi.org/10.1007/s10956-011-93575.

Vos, M. A. J., Taconis, R., Jochems, W. M. G., \& Pilot, A. (2011). Classroom implementation of context-based 
chemistry education by teachers: The relation between experiences of teachers and the design of materials. International Journal of Science Education, 33(10), 1407-1432. https:// doi.org/10.1080/09500693.2010.511 659.

Wehmeyer, M., Lattin, D., \& Agran, M. (2001). Achieving access to the general curriculum for students with mental retardation: A curriculum decision-making model. Education and Training in Mental Retardation and Developmental Disabilities, 36(4), 327-342. https://www.jstor.org/ stable/23879895?seq=1\#metadata info_tab_contents.

Winarti, A., Rahmini, A., \& Almubarak. (2019). The effectiveness of multiple 1ntelligences based collaborative problem solving to improve critical thinkıng. Jurnal Kependidikan, 3(2), 172-186. Diunduh dari https:// journal.uny.ac.id/index.php/jk/article/ view/24714/pdf.

Wiyarsi, A., \& Çalik, M. (2019). Revisiting the scientific habits of mind scale for socioscientific issues in the Indonesian context. International Journal of Science Education, 41(17), 2430-2447. https://10.1080/09500693.2019.1683912. Wiyarsi, A., \& Fitriyana, N., \& Ikhsan, J. (2019). Using technology in hydrocarbon topics: A profile on students' self-regulated learning. Journal for the Education of Gifted Young Scientists, 7(4), 983-998. http:// dx.doi.org/10.17478/jegys.616947.
Wiyarsi, A., Hendayana, S., Firman, H., \& Anwar, S. (2017) Development of learning design ability in the vocational context for pre-service chemistry teacher. Journal of Science Education, 18, 50-53. Retrieved from http://chinakxjy.com/downloads/ V18-2017-2/V18-2017-2-2.pdf.

Wiyarsi, A., Pratomo, H. \& Priyambodo, E. (2020). Vocational high school students' chemical literacy on context-based learning: A case of petroleum topic. Journal of Turkish ScienceEducation, 17(1), 147-161. http://doi.org/10.36681/tused.2020.18. Wiyarsi, A., Sutrisno, H., \& Rohaeti, E. (2018). Exploration of pre-service chemistry teacher's ability in constructing context-based content representation on electrochemistry topic. Journal of Physics: Conference Series, 1397, 012038. https://doi.org/10.1088/17426596/1397/1/012038.

Yu, K-C., Fan, S-C., \& Lin, K-Y. (2015). Enhancing students' problem-solving skills through context-based learning. International Journal of Science and Mathematics Education, 13(6), 13771401. https://doi.org/10.1007/s10763014-9567-4.

Zhang, M., Lundeberg, M., \& Ebehardt, J. (2011). Strategic facilitation of problem-based discussion for teacher professional development. The Journal of the Learning Sciences, 20, 342-394. https://doi.org/10.1080/10508406.201 1.553258 . 